\title{
Local Flows: The Pleasure-centric Turn in Human Rights Advocacy in South Asia
}

\author{
Rakhshan Rizwan, MA \\ Institute for Cultural Inquiry (ICON), Utrecht University \\ R.Rizwan@uu.nl
}

\begin{abstract}
This paper examines localized activism conducted through Anglophone Kashmiri literary fiction and by South Asian feminist social justice movements such as Girls at Dhabas and Why Loiter, in order to analyze the emergence of a pleasure-centric model of human rights advocacy in the South Asian region. Life narratives and testimonies foregrounding bodily pain, torture and victimization are ubiquitous within international human rights advocacy campaigns. South Asian activist movements have, however, suggested an alternative to this suffering-centered mode of advocacy; they foreground the effectiveness and emotional resonance of narratives of pleasure instead. This paper builds on existing scholarship focusing on the way in which insights from human rights activism conducted in local cultural contexts can be translated back to the global and how they can in turn potentially transform international practices of human rights advocacy, rather than always the other way around.
\end{abstract}

\section{Keywords}

human rights - pleasure-centric advocacy - vernacularization of law - Kashmiri fiction - Why Loiter - Girls at Dhabas - Mirza Waheed 
The post-Cold War decade of the 1990s has become recognized as the 'decade of human rights' and human rights advocacy. ${ }^{1}$ Nobel Laureate, Nadine Gordimer, referred to the Universal Declaration of Human Rights (UDHR) as '...the essential document, the touchstone, the creed of humanity that surely sums up all other creeds directing human behavior.'2 Subsequently, as argued by Ignatieff, human rights have become the '...lingua franca of global moral thought, as English has become the lingua franca of the global economy' ${ }^{3}$ Whereas human rights are the 'dominant moral vocabulary' of our contemporary world with the UDHR functioning as the seminal text of this universal vocabulary, English language, much like the latter, is extremely ubiquitous in the modern world and has been comparably translated, adopted and supplanted into different cultural, religious and legal contexts. ${ }^{4}$

However, the English of today no longer refers exclusively to the standard British English of the former imperial center, but also refers to the varieties of English spoken in various postcolonial regions in the world. ${ }^{5}$ For instance, the English spoken by Jamaicans is significantly different from the one spoken by Maoris, Canadians or Kenyans. These 'global englishes' have an impact on the 'standard English' and they are constantly engaged in a process of shaping and re-formulating their linguistic contours. ${ }^{6}$

This paper contends that in much the same way that postcolonial englishes transform the standardized British English of the imperial center, human rights activism, undertaken in the peripheries, also has an impact on the international norms of human rights advocacy and the articulation of rights on the global level. Local 'speakers' of human rights language do not straightforwardly mimic and mime a standard code of human rights, but bring their own inflections and vernacular particularities to the international discourse of human rights. In other words, human rights norms are not straightforwardly transmitted into different regions and translated into specific socio-political contexts,

1 K Schaffer, S Smith, Human Rights and Narrated Lives: The Ethics of Recognition (Palgrave Macmillan 2004) 1.

2 M Ignatieff, Human Rights as Politics and Idolatory (Princeton University Press 2003) 320.

3 Ibid.

4 M Ignatieff, 'Is the Human Rights Era Ending?' The New York Times (New York, 5 Feb 2002) <http://www.nytimes.com/2002/02/05/opinion/is-the-human-rights-era-ending.html> accessed 21 May 2017.

5 B Ashcroft, G Griffiths, H Tiffin, The Empire Writes Back: Theory and Practice in Post-Colonial Literatures (Routledge 2010) 8.

6 Ibid. 
but the expression of rights, in different geographical regions, also impacts the way in which human rights are articulated and propagated at the global level. ${ }^{7}$

\subsection{The Vernacularization of Human Rights}

Levitt and Merry have argued that global human rights norms are adopted by local activists in a process of 'cultural circulation and translation', which they refer to as 'vernacularization.8 They examine the way in which strategies of human rights advocacy and ideas of human rights are supplanted and appropriated into different social, cultural and national contexts by activists and human rights organizations operating on the ground. ${ }^{9}$ These located activists and NGOS are vernacularizers and/or translators who mediate international human rights norms and practices of advocacy to suit diverse socio-political locations and contexts, for a range of different purposes.. ${ }^{10}$

These translators should ideally be '...conversant with both sides of the exchange', transfer ideas between the peripheries and the center, and control the

'...flow of information back and forth'11 Furthermore, they should possess the expertise to translate human rights norms into local languages of human rights and justice and enable these ideas to have more resonance within local publics and thus reach a wider audience. ${ }^{12}$

Scholars have criticized the largely unidirectional transfer of human rights norms from the global to the local, as theorized by Levitt and Merry. Barnita Bagchi has criticized the 'top-down approach' to vernacularization, as propounded by them, on the grounds that '...rights activism at the local level, contributes to how rights are articulated and enshrined internationally' ${ }^{13}$ In a similar vein, Lena Khor, for example, has argued that human rights should be viewed as 'fluid, changeable and mutable' because they '...seem to travel multidirectionally back and forth between an international human rights regime

B Bagchi, 'Crooked Lines: Utopia, Human Rights and South Asian Women's Writing and Agency' (2017) Australian Journal of Human Rights 22-2, 106. in Peru, China, India and the United States' (Global Networks vol 9, No. 4, 2009) <http:// www.peggylevitt.org/assets/venacularization.pdf> accessed 21 May 2017, 443.

9 Ibid.

10 Ibid 449.

11 Ibid.

12 Ibid 448.

13 Bagchi (n 7) 106. 
and peoples and their societies, as well as within the regime, peoples and their societies. ${ }^{14}$

By building on these existing critiques of the 'top-down' model of the global diffusion of human rights, this paper will examine the suffering-centered normative model of international human rights advocacy and trace its translation, as well as transmutation, in two different local contexts. Throughout the article, one can find concrete scenarios that highlight the workings of local activism and its bearing on international human rights work. In particular, this paper draws attention to a pleasure-centered model of performing human rights work in two politically distinctive local contexts. The pleasure-centered model of human rights advocacy is positioned as a radical alternative to the dominant suffering-centered model of international advocacy.

This paper, analyzes two, what the author terms as, 'pleasure-centric advocacy campaigns' in the South Asian region, which are conducted through Anglophone fiction, ${ }^{15}$ as well as online and offline social rights activism. The author defines 'pleasure-centric advocacy' as human rights advocacy conducted through narratives and stories of pleasure and enjoyment that seek to imagine the lived experience of the human rights victim beyond experiences of abjection, physical victimization and corporeal pain. The pleasure-centric model of advocacy tries to focalize on the pleasures of everyday life and to articulate human rights atrocities holistically in terms of their ability to interrupt a life and deprive it of enjoyment and pleasure. Within this model, the human body does not merely function as corpus delicti, as the physical evidence of a human rights crime, but also as a 'vessel of pleasure' to use Elizabeth Freeman's phrase ${ }^{16}$ The body has a capacity to sustain harm, but can simultaneously also experience heightened states and experiences of happiness and enjoyment. As such, any representation of human rights atrocity should describe and delineate not only the fact of the wounding of the material and corporeal body, but also the loss of the pleasures which are central to the shared human experience.

This paper seeks to highlight first the way in which human rights ideas and languages, emanating from the center, can be forged and grafted into local contexts, and second how activism, conducted in local contexts, has the potential

14 L Khor, Human Rights Discourse in Global Networks: Books Beyond Borders (Routledge 2006) 3 .

15 Creative fiction written in English.

16 E Freeman, Time Binds: Queer Temporalities, Queer Histories (Duke University Press 2010) 16 . 
to shift forms of advocacy and practice that are de rigueur on the international level. ${ }^{17}$

This paper examines a fairly eclectic and varied corpus of 'texts' and human rights movements to draw attention to the trade-offs and exchanges between the local/regional and the international/global. The selected literature consists of human rights reports published by Amnesty International, Human Rights Watch (HRW), as well as local rights groups on the contested territory of Kashmir. In particular, Mirza Waheed's novel, 'The Collaborator', a work of Anglophone fiction composed by an author of Kashmiri descent, will be examined in detail. ${ }^{18}$ Furthermore, this paper will draw connections between local activism in Kashmir, and contemporary feminist movements in Pakistan and India such as 'Girls at Dhabas' and 'Why Loiter', both of which articulate and advocate for a human rights discourse using narratives and notions of pleasure rather than of bodily pain, suffering and victimization.

The first part of the article will explore the use of suffering and pain-centered narratives in international and local human rights reports. The author compares and contrasts the human rights advocacy conducted by traditional human rights reports with advocacy performed through literary fiction in English. In particular, they will explore the development of an alternative language of pleasure in Mirza Waheed's novel, 'The Collaborator' and the emergence of a new model of doing human rights work which could potentially transform the way in which advocacy work is done internationally. In the second part of the article, they explore contemporary feminist movements in India and Pakistan in order to further adumbrate the model of 'pleasurecentric' advocacy at work, and to outline its specific features and advantages.

Human Rights Reports: Human Rights Watch and the International Peoples' Tribunal on Human Rights and Justice in IndianAdministered Kashmir

The contested territory of Kashmir is one of the most densely militarized regions in the world. The present-day conflict has its origins in the partition and decolonization of the Indian subcontinent and the emergence of India and Pakistan as sovereign nation-states in $1947 \cdot{ }^{19}$ The Indian state has continued to maintain its military presence in Jammu and Kashmir for the last two

\footnotetext{
17 Bagchi (n 7) 106.

18 M Waheed, The Collaborator (Penguin Books Ltd 2011).

19 S Bose, Kashmir - Roots of Conflict, Paths to Peace (Harvard University Press, 2005) 14.
} 
decades. According to modest estimates, there were nearly 700,000 military troops stationed in the region in 2011. ${ }^{20}$

Kashmir resembles an area under siege: armed forces camps patrol the landscape, and even penetrate the residential areas, schools and neighborhoods of the local Kashmiris. ${ }^{21}$ The heightened presence of barbed wire fences, military checkpoints and armored vehicles perpetrate an atmosphere of fear and control and function as foreboding signifiers of the state in the region. ${ }^{22}$

Since 1989, almost 100,000 Kashmiri Hindus have migrated from the Valley of Kashmir to escape the violence enveloping their cities and been forced to re-locate in squalid refugee camps or reside in relative poverty in the major Indian cities. At the same time, approximately 60,000 people have been extrajudicially killed and 7000 have gone missing. ${ }^{23}$ Human rights organizations such as Amnesty International and Human Rights Watch (HRW) have been instrumental in bringing human rights abuses taking place in Kashmir to the forefront, and in highlighting the subjugation of both Kashmiri Pandits and Muslims.

\subsection{HRW Report}

In September, 2006, HRW published a report titled, 'Everyone Lives in Fear: Patterns of Immunity in Jammu and Kashmir' in which it drew attention to the systematic human rights abuses, such as the high incidents of extrajudicial killings, torture and gendered violence, that is being perpetrated by the Indian armed forces in the region. The report was the culmination of two years of extensive field research conducted by HRw's team on the ground, and also through telephone, email and meetings with NGOs and high-ranking government officials in the region. Ron Dudai has stated that the human rights movement has given us '...a new vocabulary, new standards, new mechanisms and a new literary form: the human rights report'. ${ }^{24}$ These reports typically focus on 'sensitive, emotional [and] controversial topics' and the human rights reports

$20 \quad$ S Kak, Until my Freedom has come (Penguin Books India 2011) 4.

21 Ibid 4.

22 T Dorabji and S Rahman, 'Makers of Memory: Women in Occupied Palestine and Kashmir' <jaggerylit.com/makers-of-memory-women-in-occupied-palestine-and-kashmir/> accessed 22 June 2017.

23 N Kaul, 'Kashmir- a Place of Blood and Memory' in S Kak (eds), Until my Freedom has come (Penguin Books India, 2011) 204.

24 R Dudai, 'Advocacy with Footnotes: The Human Rights Report as a Literary Genre' (2008) 28 Human Rights Quarterly 3, 783-795. 
produced by the HRW are no different insofar as they investigate the issue of extra-judicial killings and institutionalized torture in Kashmir. ${ }^{25}$

The content of the human rights report consists of a trenchant, legal analysis of the human rights situation in Kashmir, alongside unedited first-person and/or eyewitness testimonies from victims and bystanders who either have experienced an atrocity themselves, or witnessed it happening to someone else. Poignant eyewitness accounts and testimonies provide the reader with 'emotional, non-legal language' in order to win over their sympathy and move them into solidarity with the cause being advocated. ${ }^{26}$ Parsing the field notes in search of moving testimonies is an essential part of drafting a human rights report. Dudai has written that: 'everyone who wrote a report would recognize it: the stage when you look for the most emotive, testimonial passage to insert between Geneva Convention this and International Covenant that'. ${ }^{27}$ Most of the testimonies included within the HRW's report explicitly foreground the physical pain and suffering of the victim. This is evident in the following testimony:

[T] hey wanted revenge and so they tortured my brother and then they killed him. His ribs and legs were fractured and there was a red mark around his neck. They must have strangled him. ${ }^{28}$

Other testimonies describe the gendered and sexualized nature of the violence intended to emasculate and sexually humiliate young Kashmiri males. In this testimony too, the physicality of the encounter and the corporeal pain endured by the subject are always at the forefront of these first-person narratives:

[I] curse my brother for what he brought upon me. But more than that I curse the soldiers. I was only a boy at that time. They would strip me, make my lie naked on the floor, kick and beat me, split my legs wide apart and leave me tied up like that for hours. When I thought I could not bear any more pain, they would give me electric shocks. ${ }^{29}$

\footnotetext{
25 Ibid 784.

26 Ibid 790.

$27 \quad$ Ibid 791.

28 'Everyone Lives in Fear: Patterns of Impunity in Jammu and Kashmir' <https://www.hrw .org/report/2006/og/11/everyone-lives-fear/patterns-impunity-jammu-and-kashmir > accessed 17 March 2017.

29 Ibid.
} 
Narratives of suffering, especially embodied suffering, are at the core of international human rights campaigns and discourses, and go hand in hand with one another. Mooney, in her seminal text, 'Human Rights and the Body: Hidden in Plain Sight', has posited that the human rights discourses and practices should be looked at primarily through the frame of the human body. ${ }^{30}$ For her, 'human embodiment and suffering' is universal and central to the human condition. ${ }^{31}$

The purpose of human rights law and politics is widely believed to be the prevention of '...human suffering of both acute and chronic kinds.' ${ }^{32}$ For example, Wendy Brown views human rights as a '...defense against power and a protection against pain, deprivation or suffering. ${ }^{33}$

Judith Butler has argued that global vulnerability should be the "basis of humanism'. ${ }^{34}$ She interchangeably uses the terms 'common human vulnerability' and 'common corporeal vulnerability' to describe a sense of community borne out of our shared susceptibility to and fear of bodily harm and violence. ${ }^{35}$ Along the same lines, Pramod K Nayar has stated that '...affective accounts of suffering (...) retain (...) purchase in global consciousness.' ${ }^{36}$ To him, human rights narratives are instrumental in the recognition of the 'universality of human suffering. ${ }^{37}$

Moore and Goldberg have, on the other hand, focused on the barriers to the expansion of human rights and human rights advocacy. They have argued that '...leaps of both literacy and translation are needed to facilitate the shareability of and thus response-ability to suffering. ${ }^{38}$ Put in another way, this means that the diffusion and vernacularization of global rights discourses is connected to the translation and distribution of stories of corporeal suffering on one hand, and the generation of an effective and coherent global response to these narratives of pain on the other.

30 A Mooney, Human Rights and the Body: Hidden in Plain Sight (Ashgate Publishing 2014) 2.

31 Ibid.

32 E S Goldberg and A S Moore (eds), Theoretical Perspectives on Human Rights and Literature (New York: Routledge, 2012).

33 W Brown, 'The Most We Can Hope For...' < https://muse.jhu.edu/article/169139> accessed 21 June 2017.

34 J Butler, Precarious Life the Powers of Mourning and Violence (London: Verso, 2006).

35 Ibid 30-42.

36 K Pramod <http://postcolonial.org/index.php/pct/article/view/1078> accessed 17 March 2017.

$37 \quad$ Ibid 4.

$38 \quad$ Moore and Goldberg (n 32$) 12$. 


\section{$2.2 \quad$ IPTK}

Local rights groups in Kashmir have also incorporated the generic conventions of the international human rights report and the thematic focus on narratives of suffering. For example, in December 2009, the International Peoples' Tribunal on Human Rights and Justice in Indian-Administered Kashmir (IPTK), a local human rights group, published its findings in a human rights report titled, 'Buried Evidence: Unknown, Unmarked, and Mass Graves in IndianAdministered Kashmir. ${ }^{39}$ The IPTK is a constituent of The Jammu Kashmir Coalition of Civil Society (JKCCS), an umbrella organizing comprising of different '...non-profit, campaign, research and advocacy organizations based in Srinagar, Jammu and Kashmir. 40

The IPTK is made up of local human rights activists, academics, lawyers as well as lay participants from Kashmiri civil society. It aims to discover, investigate and dissect instances of '...institutionalized violence, social trauma and human rights abuses' in the Jammu and Kashmir region. ${ }^{41}$ In their report, the IPTK investigated and confirmed the existence of 2,700 mass graves in three districts in Kashmir; Kupwara, Bandipore and Baramulla, which are located close to the Line of Control (LOC). The Line of Control is the 'de facto border' between Indian and Pakistan-administered Kashmir that 'originated in January 1949 as a ceasefire line between the Indian and Pakistani armies at the end of their first war over Kashmir', ${ }^{42}$ Although both India and Pakistan agreed to 'respect' the LOC as a demarcating line following the Simla Agreement of 1972, the LOC does not constitute a 'de jure international border' dividing two countries. ${ }^{43}$

The IPTK's report makes use of 'next-of-kin, community and collective testimony', photographic evidence and archival research as part of its fact-finding mission to categorically prove the existence of unmarked mass graves in Kashmir. The report is divided into six chapters, and each chapter begins with a

39 A P Chatterji, P Imroz, G Navlakha, Zahir-Ud-Din, M Desai, K Parvez, 'Buried Evidence: Unknown, Unmarked, and Mass Graves in Indian-Administered Kashmir: A Preliminary Report' (International Peoples' Tribunal on Human Rights and Justice in IndianAdministered Kashmir, November 2009) <http://www.kashmirprocess.org/reports/ graves/o1Front.html\#TitleAuthors $>$ accessed 21 May 2017. 'What Is JKccs?' <www.jkccs.net> accessed 11 June 2017. 'Premise and Objectives. International People's Tribunal on Human Rights and Justice in Indian-administered Kashmir. International People's Tribunal on Human Rights and Justice in Indian-administered Kashmir' < http://www.kashmirprocess.org/premise .html $>$ accessed 12 June 2017 .

42 S Bose, Kashmir: Roots of Conflict, Paths to Peace (Cambridge, MA: Harvard UP, 2005) 178.

43 Ibid. 
colored, high-resolution photograph of unmarked graves, which are close to residential areas or on anonymous mountain slopes. These photographs are accompanied by labels outlining the location of the graves. Furthermore, the report uses tables to document the total number of dead bodies exhumed in each of the districts investigated, and these bodies are then further categorized into three categories: 'unnamed graves', 'graves with two bodies' and 'graves with more than two bodies' (See Table 1$) \cdot{ }^{44}$

Table $1^{45}$ is taken from the IPTK's human rights report and documents the distribution and number of bodies discovered during the human rights investigation:

The aim of this human rights report is to scientifically tabulate the bodies and record their numbers and distribution in villages located in four districts. In Chapter IV, titled 'Exhumed Truths', the report records the number of bodies found in each village, and provides a name of the villages investigated within each of the provincial districts. For example, in the village of Trehgam in Kupwara district, nearly 100 graves were discovered of which 83 were unnamed, and similarly, Regipora had 260 graves of which 258 were unmarked. The method with which the bodies came to be buried, as well as burial rites

TABLE $1 \quad$ Mass Graves in Kashmir

\begin{tabular}{|c|c|c|c|c|}
\hline District & $\begin{array}{l}\text { Graves } \\
\text { documented by } \\
\text { the IPTK }\end{array}$ & $\begin{array}{l}\text { Unnamed } \\
\text { graves (of those } \\
\text { documented) }\end{array}$ & $\begin{array}{l}\text { Graves with } \\
\text { bodies }\end{array}$ & $\begin{array}{l}\text { Graves with } \\
\text { more than two } \\
\text { bodies }\end{array}$ \\
\hline $\begin{array}{l}\text { Baramulla } \\
33 \text { villages } \\
\text { investigated }\end{array}$ & $\begin{array}{l}1122 \\
\text { w. } 1321 \text { bodies }\end{array}$ & $\begin{array}{l}1013 \\
90.3 \text { percent }\end{array}$ & 140 & $\begin{array}{l}17 \text { [total } 76+ \\
\text { bodies] }\end{array}$ \\
\hline $\begin{array}{l}\text { Kupwara } \\
14 \text { villages } \\
\text { investigated }\end{array}$ & $\begin{array}{l}1453 \\
\text { w. } 1487\end{array}$ & $\begin{array}{l}1278 \\
87.9 \text { percent }\end{array}$ & 8 & $\begin{array}{l}4 \text { [total } 30 \\
\text { bodies] }\end{array}$ \\
\hline $\begin{array}{l}\text { Bandipora } \\
8 \text { villages } \\
\text { investigated }\end{array}$ & $\begin{array}{l}125 \\
\text { w. } 135 \text { bodies }\end{array}$ & $\begin{array}{l}82 \\
65.6 \text { percent }\end{array}$ & 6 & $\begin{array}{l}2[\text { total } 6 \\
\text { bodies] }\end{array}$ \\
\hline $\begin{array}{l}\text { Total } 3 \text { districts } \\
55 \text { villages }\end{array}$ & $\begin{array}{l}\text { Total } 2700 \mathrm{w} . \\
2943+\text { bodies }\end{array}$ & $\begin{array}{l}\text { Total } 237387 \cdot 9 \\
\text { percent }\end{array}$ & $\begin{array}{l}\text { Total } 154 \mathrm{w} . \\
308 \text { bodies }\end{array}$ & $\begin{array}{l}\text { Total } 23 \mathrm{w} . \\
112+\text { bodies }\end{array}$ \\
\hline
\end{tabular}

$44 \quad$ Chatterji et al (n 39).

45 Ibid 11. 
involved are also listed in the report. After their demise, bodies were usually '... handled by military and paramilitary personnel, including the local police' and ordered to be buried in secret, clandestine graveyards. ${ }^{46}$

There is a latent and discursive power in numbers. Brian Root has argued that '...human rights fact-finding is a largely quantitative affair' and it is common to find '...casualty count studies, victim surveys and advanced statistical analyses' within human rights advocacy work. ${ }^{47}$ Numbers, after all, offer the reader a sense of certainty and 'precision' and are an integral component of bringing human rights issues to the attention of the world. ${ }^{48}$ Quoting numbers which often seem opaque and irrefutable is a 'powerful political tool' that can be used to convince an audience of the truthfulness of the claims being made. ${ }^{49}$ Root has written that, 'the power of statistical analysis within the advocacy is clear: numbers, usually big numbers, compel attention. Human rights advocacy organizations understand this and attempt to cite numbers wherever possible. 50

The descriptions of the cadavers in the IPTK's report also emphasize the suffering and physical pain that preceded their untimely demise, and echo the suffering-centered language of HRW's report. The bodies are described as having been 'torched to death' in the Baramulla district. ${ }^{51}$ In another case, the skulls and skeletons of the victims are mentioned as appearing to be 'extensively damaged.' ${ }^{52}$ Furthermore, the report draws attention to the fact that, '... the bodies buried in the 2,700 graves investigated by the IPTK were routinely delivered at night, some bearing marks of torture and burns. ${ }^{53}$ Testimonies, deliberately emphasizing the physical suffering borne by the victim prior to their death, were included in the report to contribute to the emotional and affective appeal of the reader. This can be seen in the following testimony:

[T] he left side of his face was mutilated. I suppose they had fired bullets in his head. His shirt was burnt, his eyes had been gouged out, and many parts of his body bore injury marks as if he had been hit by explosives. ${ }^{54}$

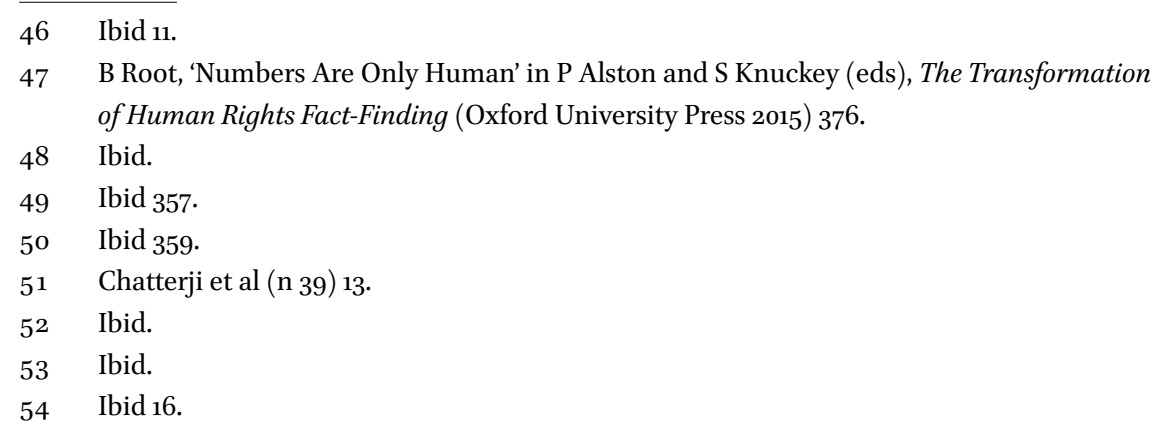


A testimony collected from a man from Trehgam village in Kupwara district bears witness to incidents of bodily torture and defilement that Kashmiri victims of abuse underwent:

$[\mathrm{M}]$ ost of the dead bodies brought here were disfigured and disfigured. Mostly the dead were undressed, their hands were tied with rope, their throats had been slit, and they had amputated legs or arms and mutilated faces, probably for concealing their identity. ${ }^{55}$

\subsection{Analysis of the Reports}

The human right report's generically focus on descriptions and testimonies that emphasize suffering, and bodily pain are translated - carried across - as it were, from the global to the local. Arguably for this reason, the rhetorical language of the HRW's report bears a striking resemblance to that of the IPTK's report, despite the differences in their investigative and forensic findings. In this way, these two human rights reports give us concrete examples of the way in which global human rights forms, normative discourses and practices, are transplanted, untouched, into local contexts, and ethical appeals on behalf of the local community are couched using the language of human rights.

\subsubsection{Corpus Delicti: The-Body-as-Witness}

The focus on tabulating and classifying bodies, and of tracing, documenting and describing their bodily suffering is connected to the significance of corpus delicti in the human rights advocacy paradigm. Renshaw has argued that 'the body-as-witness has become a troupe of the reckonings that follow acts of violence. ${ }^{56}$ In situation where human rights atrocities have occurred, the body functions as the absent/present witness to acts of violence. ${ }^{57}$ She, alongside other scholars, has articulated reasons as to why physical evidence has emerged as the focal point of human rights investigations:

[T] he privileging of physical evidence, including human remains, in investigations into the traumatic past is thought to counteract some of the anxieties around the fallibility of human memory, the act of witnessing, and the construction of narratives about the past in testimony. ${ }^{58}$

\footnotetext{
$55 \quad$ Ibid 49 .

56 L Renshaw, Exhuming Loss: Memory, Materiality and Mass Graves of the Spanish Civil War ( $1^{\text {st }}$ ed, Routledge 2011) 10.

57 Ibid 14.

58 Ibid.
} 
Thomas Lacqueur has referred to the body as the corpus delicti which according to the Campbell Black 'Law Dictionary' refers to the 'body or substance of a crime which ordinarily includes two elements: the act and the criminal agency of the act.59 Lacqueur has highlighted how the unearthing of corpus delicti, and the facts surrounding its physical state, have '...become a central and much publicized aspect of international human rights work'.60 Contemporary human rights is focused almost exclusively on dead bodies and corpus delicti have a '...privileged space in human rights discourse'. ${ }^{11}$ The bodies of human rights victims are 'physical evidence' of the crimes committed against them and as such, burial and forensic sites where these bodies have been buried often constitute the locus of human rights inquiries. ${ }^{62}$

Human rights workers consider the corpus delicti to be the 'particular, corporeal and substantial fact' that establishes the perpetration of a human rights atrocity. ${ }^{63}$ The corpus delicti is an 'articulate witness to a crime' that has been committed. ${ }^{64}$ The corpus delicti stands at 'ground zero' and experts must use his remains to build and develop a 'narrative of truth and specificity'.65

For example, in former Yugoslavia, bodies that had been extra-judicially killed bore traces of the crime and these traces were used by experts, human rights workers, forensic scientists and lawyers to uncover what perspired in the circumstances. ${ }^{66}$ Lacqueur, by referring to the corpus delicti as the 'kernel of truth', lucidly describes the process of writing the narratives of the human rights victims in former Yugoslavia in the following manner:

[T] hat man is gone; he is dead; his body reveals he did not die from natural causes; there is a bullet wound in the head. Someone caused it to be there. And we (...) can from this kernel of truth write a narrative with political, juridical, and more intimate, memorial and therapeutic consequences. ${ }^{67}$

59 T Lacqueur, 'The Body and Human Rights' in S Sweeney and I Hodder (eds), The Body (Cambridge University Press 2002).

60 Ibid.

61 N J Gates-Madsen, Trauma, Taboo, and Truth-Telling: Listening to Silences in Postdictatorship Argentina (University of Wisconsin Pres 2016) 56-57.

62 Ibid 57 .

63 Lacqueur (n 59) $76-77$.

64 Ibid.

65 Ibid.

66 Ibid.

67 Ibid. 
Another example is the way in which members of the IPTK make sense of damaged and charred bodies and bones that are discovered during the exhumation process. They use physical evidence related to the body as well as testimonies pertaining to the appearance of the body at the moment of discovery to piece together a narrative about the circumstances that transpired preceding and at the time of its death. An eyewitness testifies to the fact that:

[O]nce a completely scorched body was brought from Gagonoosa village and was handed over to us. The deceased had been scorched by army troops in the grass in Gagnoosa and then we buried that torched body here. ${ }^{6}$

The investigators and forensic experts, like Lacqueur, use the body as a 'kernel of truth' and arrive at the conclusion that bodies are, at times, incinerated or burnt in order to conceal their identities and make the process of identifying them difficult, if not, impossible. ${ }^{69}$ Through this concealment, military officers are able to frame local Kashmiri subjects as 'foreign militants' illegally infiltrating the borders with insidious motives and being shot on sight, as a result.70 'Encounter killings' are extra-judicial killings of civilians while they are in the custody of the state forces but are presented by state officials as killings, which transpired in the event of an armed confrontation between the military and foreign-sponsored or foreign-origin fundamentalist militants. ${ }^{71}$

Thus, we can observe that the human rights reports, released by HRW and by the IPT K, both focus on corpus delicti and use textual descriptions and eyewitness testimonies to construct a narrative of the suffering human body. For Mooney, the human in human rights is a suffering, corporeal human body, over and above anything else. She has stated in clear terms that: 'the human who should be the subject of human rights is a person who lives, breathes, eats and suffers. The human we need to consider is ultimately the person, every person in pain. ${ }^{72}$ And this 'person in pain' is precisely the human figure that is represented in the two human rights reports analyzed in this paper, and used in order to stir the emotions of the readers and appeal to their moral conscience.

\footnotetext{
$68 \quad$ Chatterji et al (n 39) 49.

69 Sweeney and Hodder (n 59) 30.

70 Ibid.

71 IPTK's report 10.

72 Mooney $(\mathrm{n} 30) 10$.
} 
Ann Murphy has argued that corporeal vulnerability constitutes a powerful basis for articulations of shared humanism..$^{73}$ This would explain why the body in pain, or in danger of sustaining pain, constitutes a locus for mass human rights action and advocacy. Murphy, in her work, quotes works by Butler and Cavarero in which she observes the emergence of a 'new corporeal humanism (...) grounded in the ontological fact of vulnerability, dispossession and exposure. ${ }^{74}$ 'Bodies', she writes, '....are understood as part of a global community in which each is vulnerable to the other. ${ }^{75}$ As mentioned earlier, Butler has argued that human bodies are fundamentally vulnerable and the experience and acknowledgement of this vulnerability and precariousness is what makes us feel interconnected and relatable as human beings. ${ }^{76}$ According to Murphy, however, Butler and Cavarero do not go as far to connect their conceptualization of human vulnerability and fragility to the concept of human rights, but they do '...gesture towards the possibility of a humanistic ethic that finds its provocation in an anonymous state of corporeal vulnerability'.77 The argument that the shared vulnerability of our human bodies binds and connects us is immediately resonant and intelligible. Our common physical vulnerability functions as a motivation to protect all bodies from harm and renders them worthy and deserving of fundamental human rights.

\section{Human Rights Advocacy Through Literary Fiction: The Collaborator}

Circa 2010, a number of literary works have been published by authors of Kashmiri origin and/or or those who stand in solidarity with Kashmiris. These works publicize human rights atrocities taking place in the region. Prominent examples include Mirza Waheed's novel 'The Collaborator'78 and 'The Book of Gold Leaves', ${ }^{79}$ Rahul Pandita's 'Our Moon has Bloodclots', ${ }^{80}$ Siddhartha

73 Murphy, Ann V. 'Corporeal Vulnerability and the New Humanism' < http://onlinelibrary .wiley.com/doi/10.1111/j.1527-2001.2011.01202.x/abstract> accessed 21 June 2017.

74 Ibid.

75 Ibid.

76 J Butler, Precarious Life: The Powers of Mourning and Violence (London:Verso, 2006).

77 Murphy (n 73).

78 Waheed (n 18).

79 M Waheed, The Book of Gold Leaves (Viking 2014).

8 R Pandita, Our Moon has Bloodclots (Random House India 2013). 
Gigoo's 'Garden of Solitude,,81 Basharat Peer's 'Curfewed Night',82 and Sudha Koul's 'The Tiger Ladies', 83 to name a few.

In addition to literary narratives, other artistic forms including film, painting, digital and installation art, digital novels, rap songs and online poetry are also being utilized to articulate the human rights of ordinary Kashmiri subjects. ${ }^{84}$ Like in other zones of conflict and contestation, 'culture and cultural resistance' in Kashmir is playing a significant role in the 'larger struggle' for survival and self-determination. ${ }^{85}$

Typically, literary works, that position themselves in human rights frameworks, and attempt to do the work of human right advocacy, take on the legal task presented by corpus delicti and attempt to construct a fictional narrative of the human rights atrocity by utilizing the physical traces left on the victim's body. ${ }^{86}$ Micheal Ondaatje's critically acclaimed novel, 'Anil's Ghost', is an example of the author undertaking the precarious task of reconstructing the history of a corps that has been uncovered in a government administered area during the time of Sri Lanka's protracted civil war. ${ }^{87}$

The task of writers is, in this sense, similar to that of human rights workers, with the only notable difference being the fact that the physical evidence, and the literary narrative that is spun from it are usually fictional and a product of the author's creative imagination.

Mirza Waheed's novel, 'The Collaborator', also represents and narrativizes the corpus delicti that lie in the mass, open graves in the Valley of Kashmir, but instead of using these bodies to construct a narrative only of the human rights crime, the author uses their physical remains to textualize and represent the everyday pleasures that characterized their life, prior to the perpetration of atrocity. Through this, Waheed restores the names and stories of the corpus delicti to their corporeal remains, in an attempt to re-assign meaning, memory and context to their bodies. Waheed's literary work shows the limitations of bodily suffering as the only, or at least, the most effective basis for shared humanism and exposes lacunas in the pain-centered model of doing human rights advocacy. ${ }^{88}$

\footnotetext{
81 S Gigoo, Garden of Solitude (Rupa Publications India Pvt. Ltd. 2010).

82 B Peer, Curfewed Night (Basharat Peer 2010).

83 S Koul, The Tiger Ladies (Bacon Press Books 2002).

$84 \quad \operatorname{Kak}(\mathrm{n} 20)$.

85 B Harlow, Resistance Literature (New York: Methuen, 1987).

86 A S Moore. Vulnerability and Security in Human Rights Literature and Visual Culture (New York: Routledge Taylor \& Francis Group 2016).

87 M Ondaatje, Anil's Ghost (McClelland and Steweard Inc., Toronto 2000) 130.

88 Waheed (n 18$)$.
} 
Waheed's novel is a bildungsroman or coming-of-age narrative with a young, Kashmiri protagonist who experiences the traumatic loss of his childhood friends and the destruction of his ancestral village. A bildungsroman is typically a tale of a 'youth's apprenticeship to life' ${ }^{89}$ 'The Collaborator' is set in the late 1980s when the Kashmiri Freedom Movement, also known as the Azadi Movement, was gaining momentum and popular support in the Valley of Kashmir. During this period, the protagonist lived a protected life in Nowgam - a 'tiny, sparse hamlet' - nestling in the Kashmir Valley which was, at the time, shielded from the political turmoil enveloping in the large, urbanized cities in Kashmir. ${ }^{90}$ The protagonist leads a serene and solitary existence alongside his friends; Hussain, Gul, Ashfaq and Mohammed, a group of lively adolescents who spend their time playing cricket, composing, reciting poetry and swimming in the 'languid stream[s]' that flow from scenic, snow-capped peaks. ${ }^{91}$

The serenity of their lives is interrupted by the militarization of the border regions. The local Gujjar population is seen as complicit with the Kashmiri freedom fighters who are crossing into Pakistan from the major Kashmiri urban cities and towns to receive military training, and as such, the Indian army subjects the local community to curfews, aggressive policing and crackdowns. As a result of these tactics of punishment and control, the otherwise itinerant, detached and largely apolitical Gujjar community becomes heavily politicized. The elusive promises of azadi ('freedom') begin to resonate with the protagonist's friends and eventually all of them, with the notable exception of the bildungsheld. As such, they cross the border into Pakistan to become freedom fighters. Meanwhile, the eponymous protagonist stays behind in Nowgam and bears witness to the destructions of his native village and the disappearance and killing of his young childhood friends. ${ }^{92}$

\subsection{Storytelling in Human Rights Reports and in Fiction}

Literary fiction, such as 'The Collaborator' in particular, has been mobilized as a vehicle for garnering political traction and gaining clout in both the regional and transnational public sphere by Kashmiri cultural practitioners. Human rights reports produced by local and international advocacy organizations as well as works of narrative fiction produced by Kashmir authors are instrumental in doing the work of human rights advocacy by publicizing human rights

\footnotetext{
89 D Vanderwerken 'Wiesel's Night as Anti-Bildungsroman' in Harold Bloom (ed), Elie Wiesel's Night (Infobase Publishing 2010).

$90 \quad$ Ibid 27.

91 Ibid 7 .

92 Ibid.
} 
issues to wider publics and securing the attention of the international reading public.

McLagan has stated that '...as narratives and images of suffering travel, they have the potential to construct audiences as virtual witnesses, a subject position that implies responsibility'. ${ }^{3}$ In principle, the author argues that any consumer of a literary text is part of a community of transnational readers who could potentially be mobilized as part of what Sam Gregory refers to as a mass 'human rights action'. ${ }^{94}$ Reading and consuming literature is meant to generate an ethical response in its readers and to invite them to stand in solidarity with marginalized Kashmiri subjects. The authors of these texts aim to transform the prolific Anglophone book market into an advocacy network and its locally and globally situated metropolitan readership into a 'witnessing public'. ${ }^{95}$ Torchin has defined a witnessing public as a '...community conducive to listening and responding. ${ }^{96}$ This community or public is usually created and mobilized through performative testimonies which are successful in making 'ethical claims.' ${ }^{97}$

Unlike human rights reports published by the IPTK and $H R W$, 'The Collaborator' constructs a narrative of pleasures, rather than of bodily suffering and pain, and uses this narrative to capture the imagination, sympathy and solidarity of its regional and transnational readers. Irene Khan, Amnesty International's former Secretary General states that human rights do not necessarily have to be made using only legal precepts and laws, but must foreground the human experience, and exploit the power of the testimonial voice in order to be more efficacious, impactful and morally persuasive. Bringing these issues to the fore she has argued the following:

[O]ur challenge is to (...) reframe the debate on human rights, not only in terms of law but in terms of what is right and what is wrong ... as a moral argument based on fundamental values (...) Human rights is about values not only laws and systems, it is about voice not only text. It is about the lived experience, it is about galvanizing public imagination

93 M McLagan, 'Principles, Publicity, and Politics: Notes on Human Rights Media' (2003) 105 American Anthropologist 605, 6o9.

94 S Gregory, 'Transnational Storytelling: Human Rights, WITNESS, and Video Advocacy' (2006) 108 American Anthropologist 195.

95 Ibid.

96 L Torchin, "Ravished Armenia": Visual Media, Humanitarian Advocacy, and the Formation of Witnessing Publics' (2006) 108 American Anthropologist 214, 215.

McLagan (n 93) 215 . 
and energy... In the end, the absolute prohibition of torture and cruel, inhumane and degrading treatment rests on moral grounds. Torture is not wrong because it violates the Convention against Torture --- it is wrong because (...) it debases humanity. ${ }^{98}$

However, human rights reports are effective primarily because they rely on international human rights legislation to couch their ethical appeals. Dudai has referred to this situation as 'the catch-22' of human rights reports: even though the effectiveness of human rights NGOs has to do with their deployment of human rights jargon and the invocation of international law clauses, it is the moral and ethical concerns drive human rights organizations to engage with these issues in the first place. ${ }^{99}$

First-person testimonies, to an extent, resolve and mediate the tension between the emotional impulse of the human right report and its exclusive reliance on legal discourse and scientific data. ${ }^{100}$ These testimonies are one of the 'trade-marks' and crucial defining features of this human rights genre. ${ }^{101}$ They are frequently used by NGOs and human rights workers to provide the reader with a subjective and highly personalized language to strike an emotional chord with them and let them hear the unmediated and unfiltered 'voice' of the victim. ${ }^{102}$

Storytelling appears to be a powerful tool within human rights advocacy; with respect to both human rights reports as well as literature. Traditional human rights reports, much like creative fiction, involve elements of narrativity and storytelling insofar as they include 'unedited testimonies of victims'.103 Testimonial narratives usually tell a story, or a fragment of a story, in the hopes of attracting readers and offering them 'emotional language', which they can understand and respond to. However, testimonies constitute a small part of human rights reports, and are not able to fully resolve or overcome the dissonance between the emotional call to bear witness, which drives a human rights report one on hand, and its use of legalistic language and international conventions on the other. ${ }^{104}$

\footnotetext{
98 I Khan, 'Human rights and civil society: the last frontier' <http://www.lse.ac.uk/website -archive/publicEvents/pdf/20050119-Khan-HumanRights.pdf> accessed 11 February 2016.

99 Dudai (n 27) 790.

100 Ibid.

101 Ibid.

102 Ibid.

103 Ibid.

104 Ibid.
} 
Moreover, as Irene Khan's critique highlights, they do not go far enough in depicting the everyday lived reality of the human rights subject, or giving the reader an insight into the structural and psychosocial inequalities which characterize their lives. ${ }^{105}$ The use of numbers and legal precepts lends the findings of the report authenticity and scientific persuasiveness but can also be alienating and inaccessible to the reader.

\subsection{The Representation of Human Rights Atrocities}

Exploiting the power and ability of fiction to represent the pleasures of lived experience and to construct a powerful central subject, Waheed has humanized the corpus delicti lying in the Valley. He offers the reader a sense of their life, its rhythms, routines and pleasures, preceding the fact of their physical death and dismemberment.

One of the central, fictional subjects that Waheed presents to the reader is that of Rouf Qadri, a young Kashmiri man, whose remains lie rotting in an open mass grave in the Valley of Kashmir. His cadaver is humanized and contextualized for the reader.

The bodies in these mass graves that we encounter in 'The Collaborator' do not share the anonymity of numbers which characterizes the human rights reports published by the IPTK and HRW. In a lucid and haunting passage in the novel, the protagonist describes one of the slain Kashmiri subjects who lies in an open grave. Instead of being represented as a body that has experienced intense pain, and corporeal torture, the author represents the Kashmiri subject as a youthful, vain and handsome Kashmiri man who reeked of hair oil and had styled his locks even before setting out a dangerous, guerilla mission. This is evident in the following extract from the novel:

[I]n one of my first trips down to the valley, I felt exhausted and fell asleep alongside one of freshly arrived boys. He smelled of hair oil. He had probably combed his hair back before leaving on his mission. I talked to him or maybe I didn't, for I don't know how long I slept in his company. Seventeen small flowers had grown between his legs. His watch was still ticking and the time was quarter past three. 19 April 1993. In my wakeful dream, he said he was from Sopore and his name was Rouf Ahmad Qadri. ${ }^{106}$

Here, the identifying marker of the deceased body, is not the fact of their brutal killing, but the presence of a generous amount of 'Dabur hair oil', the grooming

105 Khan (n 98).

106 Waheed (n 18) 18. 
condiment commonly deployed as a styling gel makeshift, in his lush black hair. ${ }^{107}$ We get an embodied sense of not just his wounded physicality, but also his personality. The still-ticking watch in the text functions as a metaphor for the beating heart and endow the cadaver with a sort of post-death, existence which coupled with his freshly combed hair, contribute to the fresh, almost life-like appearance of his human remains. In another instance in the novel, the narrator recounts Rouf's testimony attesting to a privileged, upper-middle class upbringing before becoming a militant:

[H]e might have told me more about himself, his family, his life, his days in Sopore, in chotta London, his friends, his love life even - maybe, maybe, he would have told me how he grew up in that rich fruit town and how he'd had such a prosperous life. He would have told me how he was driven to school in a green Ambassador by his wealthy father's driver, wearing his new red tweeds and grey wool trousers (...) he would have told me about his visits outside Kashmir as well, when he went to Delhi, or even as far as Bombay, with his father - who travelled to big cities in India selling his apple-laden trucks for lakhs of rupees - and how his father took him to the cinema to see an English film and how they travelled by the train, even took a plane to Delhi, and saw all the big things in the world, the cities, the tall buildings, the big cars, the bright markets. ${ }^{108}$

In the above passage, 'The Collaborator' offers the reader a crucial vista into the lived experience' of Rouf Qadri in the form of the circumstances preceding the fact of his extra-judicial killing. In this example, the reader gets a reflection of not just the scattered and de-contextualized, corporeal remains lying in a grave but also of the living person; the young boy from a comfortable, upper-class background who drove to school in an expensive car and watched Hollywood films with his father.

While the testimony in a human rights report is listed by way of direct speech, this particular narration is mediated and recounted by the protagonist. It is also not comparable to a first-person testimony on account of the fact that it is a fictional narration, which tries to map the life of an imagined subject. As such, it obviously has no overt legal or juridical value.

Moreover, the narrator in this case, is not a traditional human rights worker but is an unreliable narrator, who likely suffers from PTSD and whose hallucinations are not a straightforward or truthful representation of material reality.

\footnotetext{
107 Ibid.

108 Ibid 150.
} 
The point, however, is not to grant this particular narrative the legal stature of testimony, but to view it as an attempt to reconstruct and represent parts of the victim's life, which transcend the fact of their bodily disintegration and dismemberment. In other words, those aspects of the subject's life, which are typically not given space within human rights stories, are delved into and discussed.

The death of Rouf is not exclusively represented as a physical trace on his bodily remains - a suspicious-looking wound, or a violent gash - but is constructed as the interruption of his everyday routines, rhythms and pleasures. Rather than using a language limited to physical loss, pain and bodily vulnerability, 'The Collaborator' advocates for the human rights of Kashmiri subjects by deploying a language of pleasures, including the pleasures of travelling, movie-watching and of spending quality-time with his father, which are all brought to a halt in the aftermath of his killing. Loss, in 'The Collaborator' is re-articulated as the suspension of the normal and the pleasurable, and the curtailment of the everyday and the mundane.

Waheed offers the reader an alternative language to speak about human rights atrocities and crimes against humanity besides the purely legislative, and/or suffering-centered vocabulary of human rights. Victims of atrocity in 'The Collaborator' are represented as more than the sum of their bodily injuries and mutilated parts. We meet and converse with wounded bodies in Waheed's novel but these bodies have, as paraphrased by Shakespeare, 'shuffled off' or at least, in some sense, surpassed, their 'mortal coil'.109

Elaine Scarry, in 'The Body in Pain', writes about pain's visceral and allencompassing ability to obliterate human consciousness:

[T] he objects of consciousness, from the most expansive to the most intimate, from those that exist in the space at the very limits of vision, to those that exist in the space immediately outside the boundaries of the body, from the Big Dipper down to Spain, and in through the realm of personal memories to the most abiding objects of love and belief (...) all in one patient rush are swept through and annihilated. ${ }^{110}$

Pain and death are positioned in binary opposition to human consciousness that manifests itself as the pleasures of 'personal memories' and 'objects of

109 W Shakespeare and R Hapgood, Hamlet, Prince of Denmark (Philip Edwards ed, Updated edition, Cambridge University Press 2003) 158.

110 E Scarry, The Body in Pain: the Making and Unmaking of the World (Oxford University Press, 1985) 32. 
love and belief'.111 Torture and bodily agony destroys the possibility, and even the memory, of pleasure. Testimonies that only focus on these experiences in a sense reinforce and cement the logic of unbearable pain which seeks to erase the lived experiences and personal memories of the human subject. 'World, self and voice', as argued by Scarry, '....are lost, or nearly lost, through the intense pain of torture.'112 Here, she has drawn attention to a fundamental limitation in the suffering-centered approach to human rights advocacy. By only including stories and testimonies of pain, human rights workers are not sufficiently able to mediate and undo the silence that bodily pain imposes upon the victim. They do not, as argued in this paper, go far enough in re-articulating and restoring the 'world, self and voice', which pain sought to destroy but only describe the process of annihilation. In that sense, the humiliation and dehumanization that a human rights victim suffers as a result of undergoing corporeal torture and pain can only be fully remedied by restoring that subject's remembrance of events, routines and experiences pertaining to things other than the fact of pain.

Kashmiri subjects in Waheed's novel are represented as human subjects with their distinctive and individual identities who are and/or desire to be immersed in their everyday pleasures. In this context, human rights violations are conceptualized as more than incidents of violence, which damage, maim or destroy the body; they are also posited as events that interrupt the pleasures of the local population. By the same token, human rights in Anglophone Kashmiri fiction are represented as promises that guarantee access to every day pleasures, central to the human experience, in addition to safety and security from bodily harm as well as the preservation of physical autonomy and integrity. By foregrounding the significance on pleasures in shaping the human experience, 'The Collaborator' steers back the discussion to 'the human' in human rights. The power of literary representation provides us a window through which the reader can view what that human may look like and the types of aspirations they might harbor.

In that sense, Rouf Qadri is a metonymic stand-in for the multiple corpora delicti, the eponymous bodies of Kashmiris that were unearthed in mass graves in the region over the last few years. This is indicated by the fact that Waheed refers to the youths lying unclaimed in the Valley, as 'scores of Roufs', each with their own background, their family, their life, their friends and their

\footnotetext{
111 Ibid.

112 Ibid 35 .
} 
love lives. ${ }^{113}$ The victim of atrocity - Rouf Qadri, confides the circumstances surrounding his own demise to the narrator and the reader.

\subsection{From the Local to the Global}

Waheed's novel is an example of local human rights advocacy conducted through the medium of fiction. Rather than merely translating and adopting the global norms of doing human rights advocacy, this work offers readers and international human rights workers, a starkly different language for performing the work of human rights, and winning over the sympathy and interest of its publics.

Victims of human rights are more than damaged bodies punctuating a distant, macabre geography, with only their tortured limbs and body parts to bear witness to their traumatic past. Within Waheed's text, they emerge as life-like, and highly articulate beings, whose stories, personal memories and pleasures in a land considered to be a pastoral paradise are re-discovered and re-imagined.

Nancy Gates-Madsen states that there is a '...fundamental tension in human rights discourse between focusing on the body of a disappeared person as evidence of a crime or as an individual with a unique life story.'114 She uses the example of 'I Remember Julia', a testimonial text, in which Eric Carlson traces the circumstances of the death but also the life of Julia, by collecting oral testimonies from people who had been associated with her, her family and loved ones, in order to construct a portrait of the person before they became a human rights victim. ${ }^{115}$ Madsen has stated that '.... focus on material remains precludes consideration of the lives and politics of the missing' and as such may not be sufficient in giving us a comprehensive sense of their personhood. ${ }^{116}$

'The Collaborator', similar to 'I Remember Julia', acknowledges the victimization or death of the subject, but it also offers the reader a richer and more comprehensive view of the identity and experiences of the subject. Whereas 'I Remember Julia' collects testimonies connected to Julia's political life and her identity as a medical student, 'The Collaborator' instead of only probing the many identities of the human rights victim, specifically represents and narrativizes experiences of pleasure, and it is this pleasure-centric impulse which, to an extent, differentiates it from Carlson's testimonial narrative.

\footnotetext{
113 Waheed (n 18) 150.

114 Gates-Madsen (n 62) 54.

115 Ibid.

116 Ibid 57 .
} 
The insights and rhetorical strategies utilized and employed in creative fiction, can be potentially carried over and translated into the legal realm of human rights advocacy and research. Anglophone Kashmiri literary texts, in a sense, question the language of physical victimization and the sufferingcentered plots that are used in the testimonies found in traditional human rights reports. Such texts subvert the global norms of human rights advocacy by providing us with a different language, and a radically altered strategy, to articulate and publicize human rights violations and to create awareness about the issues faced by marginalized communities.

The pleasure-centered mode of advocacy that we observe in Kashmiri fiction is to an extent related to and has linkages with transformation in human rights advocacy in the South-Asian region, particularly in the arena of feminist struggle and contestation. This section explores activism undertaken by two advocacy groups; 'Girls at Dhabas' in Pakistan and 'Why Loiter' in India, both of whom have, to an extent, re-figured the conversation on gender rights and freedoms in the region.

The traditional, paternalistic dialogue on women's rights and mobility in South typically focuses on the protection of women against rape, assault and other forms of sexual violence. ${ }^{117}$ This discourse has been turned on its head by local advocacy groups that conversely focus on the pleasures of women, particularly those that are enacted, performed and claimed in public spaces. Here again, we have an example of a local rights movements reclaiming the idiom and language of pleasures as a potential tool for doing advocacy, generating public interest and pushing for the rights of women in the region. In doing this, these feminist collectives offer an alternative to the globally dominant model of advocacy work, which relies on moving testimonies pertaining to bodily suffering endured by victimized subjects.

The activist movement 'Why Loiter' frames acts of loitering, lingering and loafing in public spaces as canny, feminist initiatives that are central to the achievement of equal rights. As such, they encourage women from across religious, class, caste and ethnic lines, to saunter, linger and loaf in public. This movement was inspired by a scholarly work bearing the same name, titled as,

117 R Chatterjee, '\#WhyLoiter Reclaims Public - and Inner - Space for Indian Women’ <https:// www.pri.org/stories/2015-09-17/whyloiter-reclaims-public-and-inner-space-indian -women> 17 March 2017. 
'Why Loiter? : Women and Risk on Mumbai Streets', in which Phadke et al have argued the following:

[P]leasure, in and of itself, is low on the list of priorities of not just city planner, but also feminists. Feminists are often wary of demanding pleasure as it be might be seen as frivolous or worse irrelevant to a discussion on urbanism. Loitering then is not very likely to find a place in a feminist list of demands (...) However, the struggle against violence and the quest for pleasure cannot be separate things. The quest for pleasures actually strengthens our struggle against violence, framing it in the language of rights rather than protection. (...) We seek to claim not just the right to work but the right to play the right to unadulterated and unsanctioned pleasure. ${ }^{118}$

Why Loiter transformed into '\#Why Loiter', an activist movement conducted in the public space, as well as on the Internet and social media platforms. It encouraged, documented and promoted women loitering in and seeking pleasure in public spaces together. The Why Loiter community and events were founded and organized by Neha Singh, a Mumbai-based author and activist, who alongside a group of female friends, went to a public park which was usually populated by men, and lay in the grass. ${ }^{119}$ They took photographs, and uploaded the evidence of their pleasurable loitering on social media. Later, it generated immense public interest, and resulted in the formation of a small WhatsApp group and eventually a Facebook page, which to date has 5,772 members, with many more joining the ranks every day. ${ }^{120}$ Participants on the Why Loiter Facebook page organize loitering events at public places, tea-houses, street corners and parks. For instance, one post on the group reads: 'Join us tomorrow for a \#pleasurepockets walk in \#ahmedabad' and includes the time, the date and the location of congregation alongside a picture of young, middle-class women loitering on the seaside. An Indian woman named Neetole Mitra posts a smiling selfie of herself unaccompanied by the seaside, or indulging in street side dining, close to a crowded railway station in Chennai. These acts of claiming space and pleasure have attracted the attention of the local press including

118 S Phadke, S Khan, S Ranade, Why Loiter?: Women and Risk on Mumbai Streets (Penguin Books, 2011) 183 .

119 G Faure, 'Women in India and Pakistan Unite for the Right to Loiter' <https://www.news deeply.com/womenandgirls/articles/2017/01/13/women-india-pakistan-unite-right -loiter> accessed 17 March 2017.

120 Ibid. 
news outlets such as Scroll, The Hindu, India Express, and DNA India, to name a few, as well as international media houses, such as $B B C$ News, which covered their new year's eve loitering event, called \#IWillGoOutthat, which was organized through Why Loiter and other feminist platforms. The event sought to encourage women to step out into the streets and celebrate New Year's Eve in public.

Figure 1 is a poster for the \#IWillGoOutthat protest event designed by Arun Sekhar for the Fearless Collective on 6 January, 2017 and subsequently shared on social media. ${ }^{121}$ The Feminist Collective is a group of artists and writers who use aesthetic means to protest against gender violence. ${ }^{122}$ The Poster features a sari-clad woman with her arms stretched in a gesture of relaxed abandon while textual blurbs appear close to her limbs bearing messages such as, 'I want to walk with abandon' and 'I want to raise my eyes to the stars' which attempt to stake a claim to the pleasures of public spaces.

The Why Loiter movement has carried across into Pakistan. In 2015, a Karachi resident, Sadia Khatri, founded a corresponding movement calle, 'Girls at Dhabas', which seeks to encourage women to carve and claim public space by drinking tea at dhabas (street-side eatery) that are typically only frequented by and accessible to young men. ${ }^{123}$ The dhaba is symbolic of all public spaces, including parks, playgrounds, public walkways, inner city paths, alleys and street corners, that are male-dominated and unavailable, inaccessible or generally, unwelcoming to women, either at all hours, or at selected hours of the day.

The movement on the ground is coordinated through the Girls at Dhabas Facebook group and invites women to send submissions in the form of photographs of themselves loitering, playing cricket, cycling and dining in public spaces. In likeness to Why Loiter, Girls at Dhabas has created enormous traction for intersectional feminism and gender rights advocacy within Pakistan, and has been covered extensively by the local press, including prominent English national dailies, such as The News, and Dawn.

Cavarero has stated that there is a relationship between friendship, particularly female friendship and storytelling:

121 A Sekhar 'IWillGoOut' <https://twitter.com/povmumbai/status/817302535878901761> accessed 17 March 2017.

122 See $<$ https://fearlesscollective.tumblr.com/> accessed 17 March 2017.

123 A Sengupta, 'Feminism over Chai' <http://www.thehindu.com/features/magazine/ anuradha-sengupta-interviews-sadia-khatri-on-the-feminist-project-girlsatdhabas/ article8479509.ece> accessed 12 June 2017. 


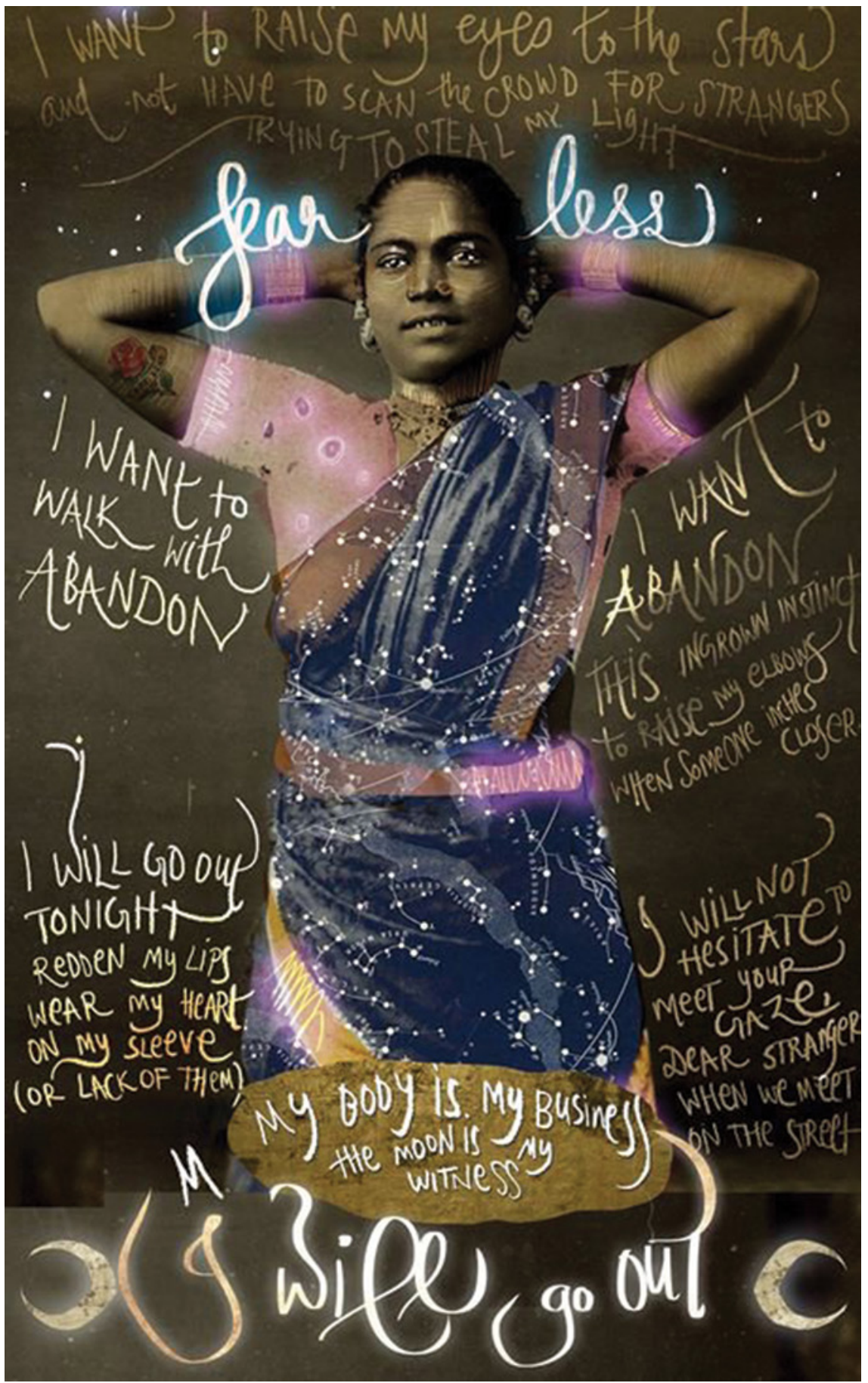

FIGURE 1 Poster for the \#IWillGoOut Protest Campaign 
[I] will tell you my story in order to make you capable of telling it to me. The narratable self's desire for narration manifests itself in autobiographical exercises in order to entrust one's own story to another's storytelling. ${ }^{124}$

In this case, the friendship and pleasure that is engendered by enactments and performances of collective loitering, is conducive to the production of personal narratives. Unlike pain, which as Scarry has argued, is the enemy of narrativity, friendship creates a physical, emotional and psychic space for the subject to engage with and articulate the full breadth and complexity of their experiences. ${ }^{125}$

\subsection{Pleasure-centric Advocacy}

The cross-fertilization of the Why Loiter social movement is a testament to the viability, currency and robustness of this pleasure-centric model of human rights advocacy in which the subject is not just a victim or physical or psychic violence, but a being with autonomy, creativity and agency who, in this case, is seeking to become positively enfranchised through access to different interpersonal, social and communal pleasures. In other words, narratives of pleasure have a special resonance amongst regional publics. Sameera Khan, the co-writer of 'Why Loiter', has argued that the message that these local feminist movements wish to convey to the 'West' is that, their lives and everyday social realities are not solely defined by violence, assault and victimhood but are infinitely more multifaceted, complex, and pleasurable. ${ }^{126}$ Girls at Dhabas and Why Loiter thus take us beyond the trope of female subject as an abject victim of sociopolitical and patriarchal violence.

Instead of a 'top-down approach' to advocacy where global norms of human rights are disseminated and artificially supplanted into local contexts, it is important to note that the means of understanding and claiming rights, as well as the pleasures being fought for, in this situation, are grounded in local idioms and social conditions. ${ }^{127}$ The pleasures of climbing trees, frequenting teahouses, napping in public parks, playing cricket, loafing in inner city streets, for instance, are connected to urban life in South Asian cities and metropolises. And the demands for greater autonomy within and claims of ownership

\footnotetext{
124 A Cavarero, Relating Narratives: Storytelling and Selfhood (Psychology Press 2000) 114.

125 Scarry (n 110).

126 D Arya, '10o Women 2016: Indian Women "loiter" in Public Places at Night' <http://www .bbc.com/news/world-asia-38031598> accessed 17 Mach 2017.

127 Bagchi (n 13).
} 
of these spaces is coming from within the ranks of feminist workers as well as lay citizens on the ground. This emergent model of pleasure-centric advocacy is an example of local activism talking back, and indeed, writing back to the dominant, global human rights discourses and regimes. It serves as an illustrative example of how locally-placed human rights workers and activists can potentially develop and transfer their own ideas about rights and activism from the local to the global, instead of the other way round.

In concordance with Sameera Khan's critique of an internationally-prevalent, victim-oriented approach for propagating and promoting gender rights in the region, Girls at Dhabas have criticized the Western press for '...their refusal to understand our norms and customs before painting us as poor, third-world women.'128 In a recent podcast uploaded on their Facebook page, they have even stated that Western coverage of Girls at Dhabas has curtailed the progress of the movement. ${ }^{129}$

Their analysis of the Western press' treatment of South Asian feminist struggle bears resonances of Mohanty's critique of Western feminist discourses. She has drawn attention to a tendency within feminist scholarship to '...colonize the material and historical heterogeneities of the lives of women in the third world, thereby producing/re-representing a composite, singular, "Third World Woman". ${ }^{130}$ She has particularly taken issue with the construction of women of color in feminist discourse as a '...homogenous powerless group often located as implicit victims of particular socio-economic systems.131

\section{$5 \quad$ Conclusion}

The activism carried out by Why Loiter and Girls at Dhabas shows us that the work of translating rights does not only involve a hierarchical transfer of international human rights norms into local contexts, but rather a mutual vernacularization of legal norms in which the local also has the opportunity to transform the global. Local and international rights vocabularies should be understood as being constantly engaged in an interminable process of dialogue,

128 'Re: Behenchara: Girls at Dhabas' <https://girlsatdhabas.tumblr.com/> accessed 17 March 2017.

129 Ibid.

130 C T Mohanty, 'Under Western Eyes: Feminist Scholarship and Colonial Discourses' [1988] Feminist Review 61, 344 .

131 Ibid 338. 
contestation and transmission across, varied, but ultimately interconnected discursive spaces.

Works, such as Mirza Waheed's 'The Collaborator' and feminist organizations like 'Girls at Dhabas' and 'Why Loiter', attest to the importance of local knowledge and to the role of creativity, pleasure and playfulness in the work of human rights activism. They highlight the subversive potential of pleasure in creating and effecting change, publicizing social issues and in building regional and transnational alliances. The pleasure-centric aesthetic of these South Asian advocacy movements has the potential to transform the norms, modes and practices of human rights advocacy on the international level. Furthermore, the insights of these forms of local advocacy can easily be carried across, translated and grafted into global contexts. Indeed, the idiom of rights in different geographical regions can have a significant impact on the way in which human rights are advocated globally.132

132 Bagchi (n 13). 